\title{
$1 \quad$ Plant seeds are primed by herbivore-induced plant volatiles
}

2

3

4 Short Title: Seed priming by HIPVs

5

6

7 Abhinav K. Maurya, Leila Pazouki, and Christopher J. Frost

8139 Life Sciences Building, Department of Biology, University of Louisville, Louisville,

9 Kentucky, 40292, USA

10

11 A.K.M. ORCID ID: 0000-0003-4251-394X

12 L. P. ORCID ID: 0000-0002-8017-5753

13

14 Author for correspondence:

15 Christopher J. Frost

16139 Life Sciences Building

17 University of Louisville

18 Louisville, KY 40292, USA

19 chris.frost@louisville.edu

20 ORCID ID: 0000-0001-5986-8646 


\section{Abstract}

24 Mature plants can detect and respond to herbivore-induced plant volatiles (HIPVs) by priming or

25 directly activating defenses against future herbivores. Whether other plant life stages can respond

26 to HIPVs in similar manners is poorly understood. For example, seeds are known to respond to a

27 variety of environment cues that are essential for proper germination timing and survival. Seeds

28 may also be exposed to HIPVs prior to germination, and such exposure may affect the growth,

29 development, and defense profiles when the seeds grow into mature plants. Here, we investigated

30 the effect of seed exposure to common HIPVs on growth, reproduction and defense

31 characteristics in the model plants Arabidopsis thaliana and Medicago truncatula. Of all the

32 HIPVs tested, indole specifically reduced both beet armyworm growth on $A$. thaliana and pea

33 aphid fecundity on $M$. truncatula. Induction of defense genes was not affected by seed exposure

34 to indole in either plant species, suggesting that seed priming operates independently of induced

35 resistance. Moreover, neither species showed any negative effect of seed exposure to HIPVs on

36 vegetative and reproductive growth. Rather, $M$. truncatula plants derived from seeds exposed to

$37 z$-3-hexanol and $z-3$-hexenyl acetate grew faster and produced larger leaves compared to

38 controls. Our results indicate that seeds are sensitive to specific HIPVs, which represents a novel ecological mechanism of plant-to-plant communication.

40

41 Keywords: Seed Priming, Herbivore-Induced Plant Volatiles, Indole, $z-3$-hexanol and $z$-3-

42 hexenyl acetate, Beet Armyworm, Pea Aphid 


\section{Introduction}

Spermatophytes (or seed plants) are a dominant clade of vascular plants on earth (Friis et al., 2011; Simonin \& Roddy, 2018). Their dominance is due to large part to the evolution of the seed, which provides protection to the embryo prior to germination and nutrition during the transition to autotrophy. One advantage of the seed is the ability to survive long periods of time in dormancy until environmental conditions are suitable for germination and growth. During dormancy, seeds are inevitably exposed to a variety of biotic and abiotic environmental conditions such as temperature, moisture, fire, soil chemicals, and chemical exudates of plant and microbial origin that may affect their germination (Fenner, 2000). Many of these conditions are well-established cues that seeds use to coordinate their physiology and metabolism to properly time germination to maximize viability and establishment (Karssen \& Hilhorst, 2000; Bentsink \& Koornneef, 2008). Temperature (Probert, 2000; Reynolds et al., 2001), rainfall (Gutterman, 1994; Pake \& Venable, 1996; Levine et al., 2008), and light (Wesson \& Wareing, 1969; Milberg et al., 2000; Flores et al., 2006) are well-documented abiotic environmental cues that affect the germination of seeds, and responses to these cues are regulated through phytohormone signaling pathways (Chen et al., 2008; Seo et al., 2008; Toh et al., 2008).

In addition to abiotic cues, seeds can perceive a variety of chemical cues of biological origins that can affect germination and subsequent defensive profiles. For example, low molecular weight phenolic compounds in soil (Muscolo et al., 2001), artemisinin released from leaves (Chen \& Leather, 1990) and catechin released from plants after herbivory (Thelen et al., 2005) inhibit seed germination. In contrast, smoke-derived karrikins (Flematti et al., 2004; Dixon et al., 2009; Nelson et al., 2012) and strigolactone (SL) phytohormones released from plant roots can stimulate seed germination (Cook et al., 1966; Bergmann et al., 1993). Moreover, recent studies have shown that seeds are receptive to the direct application of exogenous phytohormones that can activate plant defenses (Rajjou et al., 2006; Worrall et al., 2012; Jucelaine et al., 2018). For example, treating tomato seed with the phytohormone jasmonic acid (JA) and $\beta$-aminobutryric acid (BABA) lead to JA- and ethylene-dependent resistance in future plants against spider mite, caterpillars, aphids, and pathogens (Worrall et al., 2012). Seed treatment with JA also changes the volatile composition of mature plants, making their blends more attractive to predatory mites (Smart et al., 2013). Similarly, seed treatment with salicylic acid (SA) enhances the expression of SA-related genes and the endogenous SA level against root 
holoparasite (Orobanche cumana) (Yang et al., 2016). Additionally, seed coating with plant growth promoting rhizobacteria (PGPR) and plant growth promoting fungus (PGPF) enhances seed germination, seedling establishment, and boosts induced defenses in future plants in SA-, ET-, and JA-dependent manners (Ryu et al., 2004; Rudrappa et al., 2010; Sharifi \& Ryu, 2016).

Seeds also come in contact with biotic agents that are volatile. Inhibitory and allelopathic effects of some plant and microbial derived volatile organic compounds (VOCs) have been known for a long time (Muller \& Muller, 1964; Muller, 1965; Oleszek, 1987; Bradow \& Connick, 1990; Koitabashi et al., 1997; Mirabella et al., 2008). Whereas these VOCs do not necessarily provide contextual information about future environmental conditions, herbivoreinduced plant volatiles (HIPVs) represent potentially reliable and adaptive indicators of herbivory. The function of HIPVs in priming or directly inducing plant defenses is now well established (Engelberth et al., 2004; Frost et al., 2007; Rodriguez-Saona \& Frost, 2010), and exposure of undamaged plants to HIPVs is known to induce or prime the genes in phytohormone pathways (Bate \& Rothstein, 1998; Engelberth et al., 2007; Frost et al., 2008c). Moreover, aboveground HIPV priming cues are also produced belowground by plant roots (Lawo et al., 2011; Palma et al., 2012; Gfeller et al., 2013; Barsics et al., 2017) and rhizosphere organisms (Bhattacharyya et al., 2015; Kanchiswamy et al., 2015). Therefore, there are multiple routes by which seeds could be exposed to HIPVs, including simple diffusion of HIPVs produced belowground (Peñuelas et al., 2014) and precipitation and leaching of HIPVs produced aboveground (Muller et al., 1964; H B Tukey, 1970). While some HIPVs may have allelopathic effects on seed germination (Preston et al., 2002; Karban, 2007; Mirabella et al., 2008), whether exposure of seeds to HIPVs alters subsequent plant physiology and defense is currently unknown.

Here, we determined the effect of seed exposure to HIPVs on plant growth and direct defenses. Specifically, we used a comparative approach to investigate the effects of HIPV exposure to the seeds of (1) A. thaliana on the performance of a chewing herbivore (beet armyworm; Spodoptera exigua) and (2) M. truncatula on the performance of a phloem feeding herbivore (pea aphid; Acyrthosiphon pisum). We also tested the effect of seed exposure to plant volatile on the growth, development, and defense gene expression of $A$. thaliana and $M$ truncatula. We specifically tested HIPVs that have been shown previously to prime mature plants: indole, $c i s-3$-hexenol (z3HOL), cis-3-hexenyl acetate (z3HAC), $\beta$-caryophyllene (BCP), 
and trans-2-hexanol (e2HAL). We predicted that HIPV exposure to seeds would prime the resulting mature plants for enhanced resistance against both chewing and phloem-feeding herbivores.

\section{Materials and Methods}

\section{Plant material:}

A. thaliana (Col-0) seeds were surface sterilized in $75 \%(\mathrm{v} / \mathrm{v})$ ethanol for five minutes and $20 \%$ bleach $(\mathrm{v} / \mathrm{v})$ in $.01 \%$ Tween-20 for ten minutes. After sterilization the seeds were washed three times with distilled water and spread on petri-plates with wet Whatman paper. Petri plates were kept at $4{ }^{\circ} \mathrm{C}$ for 2 days, this allowed the seeds to break dormancy and synchronize germination.

M. truncatula, A-17 seeds were scarified in concentrated $\mathrm{H}_{2} \mathrm{SO}_{4}$ for 10 min and surface sterilized in $20 \%(\mathrm{v} / \mathrm{v})$ bleach in $0.1 \%(\mathrm{v} / \mathrm{v})$ Tween-20 solution for $10 \mathrm{~min}$. Seeds were rinsed five times with sterile water and were spread on petri plates with wet Whatman paper. Petri plates were covered with aluminum foil to maintain dark environment and kept at $4^{\circ} \mathrm{C}$ for two days.

\section{Seed treatment with plant volatiles}

Volatile dispensers were used to treat $A$. thaliana and $M$. truncatula seeds to individual plant volatiles. For preparing volatile dispensers $20 \mu \mathrm{l}$ of cis-3-hexenol, cis-3-hexenyl acetate (Engelberth et al., 2004), trans-2-hexenal, $\beta$-caryophyllene and $20 \mathrm{mg}$ indole (Erb et al., 2015) was added into separate $2.0 \mathrm{ml}$ amber glass vial (Agilent Technologies) with $1 \mathrm{mg}$ of glass wool (Fig. S1). Control volatile dispensers had only glass wool without any volatile. The amber vials with volatiles were sealed with a rubber septum and connected to the 2-ounce plastic cup by piercing the plastic cup and amber vial rubber septum with an 18-gauge needle. This procedure is similar to what has been used previously for controlled administration of HIPVs (Erb et al., 2015). Each volatile was administered to seeds in multiple plastic cups (biological replicates) and number of seeds planted from each plastic cups constituted the technical replicates.

\section{A. thaliana Seed germination}


Each volatile was administered to seeds in 5 replicates (plastic cups). After one day of volatile treatment, two $A$. thaliana seeds were transferred from each plastic cups to agar plates containing 1.0\% (w/v) agar (Sigma) and standard 0.5X MS medium (Murashige and Skoog basal at an adjusted $\mathrm{pH}$ of 7.0). Total 9 agar plates were used for each volatile treatment. The Petri dishes were kept in growth chamber at $25^{\circ} \mathrm{C}$ under a $16 \mathrm{~h}$ light: $8 \mathrm{~h}$ dark (16L: 8D) day/night cycle for two days. Percent seed germination was measured after two days of seed transfer from plastic cup to petri-plates.

\section{A. thaliana growth}

After one day of volatile treatment, $A$. thaliana seeds were transferred to $5.5 \times 5.5 \times 5.5$ $\mathrm{cm}$ pots filled with sterile Metro-Mix 360 soil. After transplanting, pots were placed on trays $(54 \times 28 \times 6 \mathrm{~cm})$.in a growth chamber at $25^{\circ} \mathrm{C}$ under a $12 \mathrm{~h}$ light: $12 \mathrm{~h}$ dark $(12 \mathrm{~L}$ : 12D) cycle. Once germinated seedlings reached to 4-6 leaf stage, they were fertilized twice a week with $10 \mathrm{ml} \mathrm{1/2}$ strength Hoagland's solution. Arabidopsis growth and fitness were measured in terms of number of leaves, maximum rosette diameter, the length of the bolt and number of siliques produced.

\section{M. truncatula growth}

Volatile exposed M. truncatula seeds were planted in $9 \times 6.5 \times 6.5 \mathrm{~cm}$ pots as described above. The trays were kept in growth chamber at $25^{\circ} \mathrm{C}$ under a $12 \mathrm{~h}$ light: $12 \mathrm{~h}$ dark (12L: 12D) day/night cycle for ten days. After 10 days the trays were moved to green house and kept there till the end of the experiment. M. truncatula growth and fitness were measured in terms of petiole length, leaf blade length, leaf blade width, main shoot length, axillary shoot length and number of fruits using numerical nomenclature coding system developed by Bucciarelli et al. (2006). The numerical nomenclature for vegetative growth (Fig. S3) starts with first unifoliate leaf as metamer $1(\mathrm{~m} 1)$ followed by first trifoliate as metamer $2(\mathrm{~m} 2)$ and so on. The axillary shoots are coded as per the their metamer of origin (e.g. the axillary shoot originating from first unifoliate or metamer 1 is also designated as $\mathrm{m} 1$ ). Additionally, decimal addition to numerical coding system defines the development stage of leaf (e.g. m2.1 represent the bud break for the first trifoliate, $\mathrm{m} 2.5$ represent the half open blade of first trifoliate while $\mathrm{m} 2.9$ represent fully developed first trifoliate). 


\section{Caterpillar herbivory}

Beet armyworm (Spodoptera exigua) was used to evaluate the effect of seed exposure to HIPVs on herbivore defense of Arabidopsis plants. Caterpillar eggs were ordered from Benzon Research Inc. USA (Permit \#P526P-16-02563). Egg masses were immediately transferred to artificial diet in 2-ounce plastic cups. Eggs in plastic cups were maintained at $24^{\circ} \mathrm{C}$ on artificial diet until the desired instar. Third instar caterpillars were used for feeding experiment on five to six-week-old, vegetative stage, A. thaliana plants. For the first feeding experiment, each volatile was administered to seeds in six plastic cups (biological replicates) and three seeds were planted from each plastic cups (three technical replicates). For the second feeding experiment, each volatile treatment had 10 biological replicates) and three technical replicates. For feeding experiment caterpillars were starved for 3 hours and weighed before their transfer to Arabidopsis plants. One third-instar caterpillar was placed on each Arabidopsis plants. The plants were covered with a nylon mesh bag to avoid the caterpillar escape. The caterpillars were allowed to feed freely for $24 \mathrm{~h}$ before being removed from the plants. After their removal, the caterpillars were kept at room temperature for three hours to allow the digestion of ingested plant material. Caterpillars that molted during the second experiments were removed from the assay analysis. After $3 \mathrm{~h}$ the caterpillars were weighted on microbalance. Aboveground plant material was also collected in liquid nitrogen and stored at $-80^{\circ} \mathrm{C}$ for later molecular work.

\section{Aphid herbivory}

Pea aphid (Acyrthosiphon pisum) colony was maintained on fava bean plant kept in growth chamber $\left(20^{\circ} \mathrm{C}, 12: 12 \mathrm{~h}\right.$ light:dark). For aphid feeding experiment, three adult aphids (defined as $\mathrm{F}_{0}$ generation) (Tomczak \& Müller, 2017) were placed in an insect bag (L15 X W6, BugDorm) on three trifoliate ( 8 to 10 plants per treatment). After $24 \mathrm{~h}$, the adults were removed and one trifoliate was collected while 5 nymphs (defined as $\mathrm{F}_{1}$ generation) were left on the plant for 13 more days. For 13 days the nymphs grew and produced offspring ( $\mathrm{F}_{2}$ generation). On $14^{\text {th }}$ day the all the aphids were collected, the total offspring $\left(\mathrm{F}_{2}\right)$ were counted and weighed on microbalance. Aboveground plant material was also collected on day 14 in liquid nitrogen and stored at $-80^{\circ} \mathrm{C}$ for later molecular work. 


\section{Gene expression analysis}

Aboveground tissue collected from $A$. thaliana plants after one day of caterpillar herbivory and M. truncatula after 14 days of aphid feeding were used for gene expression analysis. Total RNA was isolated from approx. $150 \mathrm{mg}$ of ground tissue using modified cetyl trimethylammonium bromide (CTAB) method (Frost et al., 2012). RNA was quantified with Nanodrop and integrity was confirmed using a native $1 \%$ agarose- $0.5 x$ TAE gel. Total RNA $(2.5$ $\mu \mathrm{g}$ per sample) was treated with DNAse (Turbo DNAse, Ambion), then $0.7 \mu \mathrm{g}$ of DNA-free RNA was reverse-transcribed to cDNA using High Capacity cDNA Reverse Transcript Kit (Applied Biosystems). Real-time PCR was done using the Quant Studio-3 PCR System (Applied Biosystems) with each reaction containing $2 \mu$ of EvaGreen ${ }^{\circledR}$ PCR Master Mix (Mango Biotechnology), $0.3 \mu \mathrm{l}$ of $10 \mu \mathrm{M}$ forward and reverse primer, $5.4 \mu \mathrm{l}$ of DI water, and $2 \mu 1$ (2.5 ng) of cDNA in a total volume of $10 \mu \mathrm{l}$. Primer specificity was confirmed by melting curve analysis, and relative transcript levels were calculated using the $2^{-\Delta \mathrm{CT}}$ method (Livak \& Schmittgen, 2001) with elongation factor 1-alpha $(E F 1-\alpha)$ and Glyceraldehyde 3-phosphate dehydrogenase $(G A P D H)$ as reference genes for M. truncatula and Actin-7 and GAPDH as reference genes for A. thaliana. Primer sequences for all M. truncatula and A. thaliana genes tested are listed in Table 1.

\section{Statistical analyses}

Raw data were checked for normality and homogeneity of variance before performing the parametric tests. For A. thaliana, leaf number, rosette diameter, were analyzed using repeated measures ANOVA. For M. truncatula, leaf petiole length, leaf blade length and width, main shoot and axillary shoot length were analyzed using one-way ANOVA followed by Dunnett post-hoc test. Other response variables for A. thaliana and M. truncatula growth along with caterpillar growth rate, aphid number and aphid weight were analyzed for significance using student's t-test. For t-test, treatments were compared to controls. The gene expression data were analyzed using one way ANOVA followed by Tukey's post-hoc test. Statistical analyses were performed using R version 3.4.2 and GraphPad Prism and figures were generated via GraphPad Prism. 


\section{Results}

\section{Seed exposure to indole enhances plant resistance against chewing and sap feeding} herbivores

Indole exposure to seeds reduced the relative growth rate of $S$. exigua caterpillars feeding on mature foliage by $33 \%(p=0.0706$, Fig. 1a) and 30\% respectively $(p=0.0124$, Fig. 1 b) in separate experiments. In contrast, seed exposure to GLVs and terpenes had no effect on caterpillar growth ( $>0.05$, Fig. 1a). We observed similar effects of indole in M. trucatula, where pea aphids fecundity and total weight were reduced by $28 \%$ ( $p=0.007$, Fig. 1c) and $41 \%$ ( $p=0.015$, Fig. 1d), respectively. Additionally, z3HAC seed treatment to M.trucatula reduced pea aphid fecundityby $27 \%$ ( $p=0.0354$ Fig. 1c) and total nymph weight by $35 \%$ ( $p=0.067$ Fig. $1 \mathrm{~d})$.

\section{Seed exposure to indole does not affect growth and development of $\boldsymbol{A}$. thaliana}

A. thaliana seed exposure to HIPVs had no significant differences relative to controls on the vegetative and reproductive growth. We found no differences in leaf number $\left(\mathrm{p}_{\mathrm{trt}}=0.997\right.$, Fig. $2 \mathrm{a})$, rosette diameter $\left(\mathrm{p}_{\mathrm{trt}}=0.672\right.$, Fig. $\left.2 \mathrm{~b}\right)$, bolt length $(\mathrm{p}=0.333$, Fig. $2 \mathrm{c})$, silique number $(p=0.460$, Fig. $2 d)$, and fresh shoot weight $(p=0.107$, Fig. $2 e)$ of plant that were grown from seeds exposed to any HIPV relative to control plants.

We also measured the effect of HIPV exposure on seed germination of $A$. thaliana on MS media. Of all the HIPVs tested, only seed exposure to the GLV e2HAL reduced seed germination by $26 \%$ compared to control seeds ( $<<0.001$, Fig. $2 f)$.

\section{Seed exposure to GLVs enhances M. truncatula growth}

M. truncatula seed exposure to $z 3 \mathrm{HOL}$ and $z 3 \mathrm{HAC}$ increased plant vegetative growth (Fig. 3a). Petiole length ( $<<0.05$, Fig. 3b), leaf blade length ( $<<0.05$, Fig. 3c), leaf blade width (Fig. 3d) and axillary shoot length (p<0.05, Fig. 3e) of the $z 3 \mathrm{HOL}$ and $z 3 \mathrm{HAC}$ exposed seed plants were higher compared to control plants while no such effect was seen on main shoot length ( $\mathrm{p}_{\text {global }}=0.016, \mathrm{p}_{\text {Dunnett's }}>0.05$, Fig. S2a). No other HIPV affected vegetative growth in $M$. truncatula. Furthermore, while $z 3 \mathrm{HOL}$ and $z 3 \mathrm{HAC}$ affected the vegetative growth, there was no difference in reproductive output of plants grown from HIPV-exposed seeds than control seeds $(p=0.929$, Fig. $S 2 b)$. 


\section{Seed exposure to indole does not affect herbivore-inducible defense gene expression after} caterpillar or aphid herbivory

Since there was a clear effect of indole seed treatment on caterpillar and aphid fecundity, we assessed whether this effect was due to indole-mediated changes in inducible defenses. In $A$. thaliana challenged with $S$. exigua, we analyzed the expression of genes related to JA synthesis ( $L O X 2$, Fig. 4a) and signaling (MYC2, Fig. 4b), and glucosinolate biosynthesis (CYB79-B2 and CYB79-B3, Fig. 4c-d). Caterpillar herbivory induced the expression of these four marker genes as expected, but indole-seed treatment neither directly stimulated nor statistically altered the caterpillar-induced expression patterns of these genes. In M. truncatula challenged with aphids, we analyzed two SA-regulated marker genes, $P R 5$ and $B G L-1$, which have previously been

273 shown to be responsive to aphid feeding (Moran \& Thompson, 2001; Gao et al., 2008). PR5 and $B G L-1$ were induced by aphid feeding (Fig. 4e-f), but indole seed treatment neither directly stimulated nor statistically altered the aphid-induced expression patterns of these genes. That is, in all cases, indole did not directly induce, indirectly prime, or affect the magnitude of herbivore induction of these defense genes.

\section{Discussion}

We show that seeds are viable receivers of HIPVs in ways that prime defenses and, in some cases, directly stimulate growth. Specifically, our study demonstrates that the pregermination exposure of seeds to indole enhances resistance against herbivores of two feeding guilds in two different plant species without any apparent effects on plant growth or fitness. Our study also showed that seed exposure to $z 3 \mathrm{HOL}$ and $z 3 \mathrm{HAC}$ can enhance plant growth in $M$. truncatula. Biotic cues that reliably indicate future biotic stress can prime plant defenses for faster and/or stronger defenses following subsequent stress events (Conrath et al., 2006; Frost et al., 2008a). The phenomenon of HIPV-mediated priming is now well established in mature plants (Engelberth et al., 2004; Frost et al., 2007; Frost et al., 2008b; Frost et al., 2008c; that seeds can also be primed by HIPVs. Moreover, seed exposure to HIPVs had no adverse effect on seed germination, vegetative growth and reproductive output of the primed mature plants (Fig. $2 \& 3$ ). Such a long-persisting defense response without apparent negative 
consequence on plant growth and development may be indicative of defense priming rather than direct activation of induced defenses.

HIPV-mediated defense priming is theoretically a component of an inducible resistance phenotype (Frost et al., 2008a; Hilker et al., 2016). Since seed treatment with defense phytohormones (e.g., JA, SA and BABA) primes defenses by modulating stress-related signaling pathways (Azooz, 2009; Worrall et al., 2012; Jucelaine et al., 2018), we hypothesized that volatile indole would prime seeds through inducible signaling pathways. We therefore predicted that seed-primed plants would show primed inducible defenses compared to controls when challenged with herbivores. For example, Worrall et al. (2012) showed that seed treatment with JA and BABA primed the antiherbivore and antipathogen defenses in mature Arabidopsis plants by JA-dependent processes. However, in our case, JA-related octadecanoid pathway (Wasternack, 2007; Ballaré, 2011) and glucosinolate biosynthesis (Hopkins et al., 1998; Reymond et al., 2004) marker genes were induced by S. exigua feeding to similar levels independent of indole seed treatment (Fig. 4). Similarly, marker genes for SA-related defense (Walling, 2008) in M. truncatula were induced by A. pisum but were not additionally enhanced by seed treatment (Fig. 4). Therefore, HIPV-mediated seed priming operates through a mechanism independent of inducible resistance. Moreover, indole seed treatment did not directly induce any marker gene before herbivory, further ruling out direct activation of induced resistance via seed priming (Fig. 4). Since we measured just single time points as indicators of inducible defense, it is possible that seed priming altered the temporal dynamics of induced defense. However, the time points we chose are reflective of sustained defense activation, which is one important aspect of defense priming. The enhanced defense in indole-exposed seed plants in our study is therefore likely a result of change in plant nutritive and defense chemistry.

Indole was the only HIPV we tested that primed plant defenses after seed exposure, and this effect was consistent across two model plants against herbivores of different feeding guilds. Indole is an ubiquitous, inter-kingdom intermediate in critical biochemical pathways (Zhang et al., 2008) and a signaling molecule (Lee et al., 2015). In plants, indole is also a common HIPV that contributes to direct and indirect defenses (Veyrat et al., 2016; Gasmi et al., 2018) and also acts as a defense priming cue (Erb et al., 2015; Ye et al., 2018). Our study adds an additional facet to the ecological role of indole in plant communication. That said, rhizosphere inhabiting bacteria also produce volatile indole, which can modulate plant growth via auxin pathway (Blom 
et al., 2011; Yu \& Lee, 2013; Bailly et al., 2014; Bhattacharyya et al., 2015). We tested the genes CYP79B2 and CYP79B3 in A. thaliana which involve in enzyme production that convert tryptophan (Trp) to indole-3-acetaldoxime (IAOx), a rate determining intermediate in auxin biosynthesis pathway and plant defense compound indole glucosinolates biosynthesis (Zhao et al., 2002). Seed exposure to indole alone did not upregulate either gene, but $S$. exigua feeding induced their expression independent of seed exposure to indole (Fig. 4. c \& d). Therefore, the auxin pathway may not be involved in indole-mediated seed priming. Nevertheless, seed priming was consistent in two different plant species against different feeding guilds of herbivores, suggesting a clear role for indole in mediating plant-seed communication.

Exposure of M. truncatula seeds to two GLVs (z3HOL and $z 3 \mathrm{HAC})$ stimulated vegetative growth. Our group has recently seen similar vegetative and reproductive growth stimulation using a low-dose, persistent application of z3HAC in lima bean plants (Freundlich \& Frost, 2018). In lima bean and M. truncatula, plants with increased growth also were better defended ( (Freundlich \& Frost, 2018) and Figs 1\&3). GLVs are well-established priming cues against biotic stress (Engelberth et al., 2004; Frost et al., 2008c), and volatile communication between plants can alter biomass allocation (Ninkovic, 2003). Our results suggest that GLVs can also stimulate plant growth and ostensibly overcome the growth-defense dilemma (Herms \& Mattson, 1992) in some plant species. One caveat, though, is that our group also has shown that persistent exposure to z3HAC reduces growth in Capsicum annuum (Freundlich \& Frost, 2018), therefore the stimulating effect of GLVs is not universal.

As a final point, our results have potential applications in pest control and seed management. Recent attention has focused on leveraging priming of innate plant immunity (Pichersky \& Gershenzon, 2002; Dervinis et al., 2010; Song \& Ryu, 2013; Song et al., 2015; Pickett \& Khan, 2016), due in part to presumed lower fitness costs of priming based defenses (van Hulten et al., 2006; Buswell et al., 2018). In-field foliar or soil application of these agents can induce plant defenses against herbivores (Bruce et al., 2003; War et al., 2011; Song \& Ryu, 2013), but can also be prohibitively costly for large-scale application. In contrast, seed treatments are a common method of inoculating crops (Paparella et al., 2015), and direct application of HIPVs to seeds could provide more viable priming-mediated solution to pest management. Moreover, $M$. thaliana is a close relative of fodder crop alfalfa, and improved vegetative growth after seed treatment with GLVs may provide a mechanism for enhancing fodder capacity and 
rejuvenating soils during crop rotations. Furthermore, HIPV-mediated seed priming may be a valuable tool in conservation efforts for rare or endangered species (Laetz et al., 2009), if HIPVmediated seed priming can enhance their innate immunity. Ultimately, seed priming via HIPVs represents a novel mechanism in plant-plant communication that may have trans-generational effects on ecological communities.

\section{References}

Azooz M. 2009. Salt stress mitigation by seed priming with salicylic acid in two faba bean genotypes differing in salt tolerance. International Journal of Agriculture \& Biology 11(4): 343-350.

Bailly A, Groenhagen U, Schulz S, Geisler M, Eberl L, Weisskopf L. 2014. The inter-kingdom volatile signal indole promotes root development by interfering with auxin signalling. The Plant Journal 80(5): 758-771.

Ballaré CL. 2011. Jasmonate-induced defenses: a tale of intelligence, collaborators and rascals. Trends in plant science 16(5): 249-257.

Barsics F, Delory BM, Delaplace P, Francis F, Fauconnier M-L, Haubruge É, Verheggen FJ. 2017. Foraging wireworms are attracted to root-produced volatile aldehydes. Journal of Pest Science 90(1): 6976.

Bate NJ, Rothstein SJ. 1998. C6-volatiles derived from the lipoxygenase pathway induce a subset of defense-related genes. The Plant Journal 16(5): 561-569.

Bentsink L, Koornneef M. 2008. Seed dormancy and germination. The arabidopsis book 6: e0119-e0119.

Bergmann C, Wegmann K, Frischmuth K, Samson E, Kranz A, Weigelt D, Koll P, Welzel P. 1993. Stimulation of Orobanche crenata seed germination by (+)-strigol and structural analogues dependence on constitution and configuration of the germination stimulants. Journal of Plant Physiology 142(3): 338-342.

Bhattacharyya D, Garladinne M, Lee YH. 2015. Volatile indole produced by Rhizobacterium Proteus vulgaris JBLS202 stimulates growth of Arabidopsis thaliana through auxin, cytokinin, and brassinosteroid pathways. Journal of Plant Growth Regulation 34(1): 158-168.

Blom D, Fabbri C, Connor EC, Schiestl FP, Klauser DR, Boller T, Eberl L, Weisskopf L. 2011. Production of plant growth modulating volatiles is widespread among rhizosphere bacteria and strongly depends on culture conditions. Environmental Microbiology 13(11): 3047-3058.

Bradow JM, Connick WJ. 1990. Volatile seed germination inhibitors from plant residues. Journal of chemical ecology 16(3): 645-666.

Bruce TJA, Martin JL, Pickett JA, Pye BJ, Smart LE, Wadhams LJ. 2003. Cis-Jasmone treatment induces resistance in wheat plants against the grain aphid, Sitobion avenae (Fabricius) (Homoptera: Aphididae). Pest management science 59(9): 1031-1036.

Bucciarelli B, Hanan J, Palmquist D, Vance CP. 2006. A standardized method for analysis of Medicago Truncatula phenotypic development. Plant physiology 142(1): 207-219.

Buswell W, Schwarzenbacher RE, Luna E, Sellwood M, Chen B, Flors V, Pétriacq P, Ton J. 2018. Chemical priming of immunity without costs to plant growth. New Phytologist 218: 1205-1216.

Chen H, Zhang J, Neff MM, Hong S-W, Zhang H, Deng X-W, Xiong L. 2008. Integration of light and abscisic acid signaling during seed germination and early seedling development. Proceedings of the National Academy of Sciences 105(11): 4495-4500. 
Chen PK, Leather GR. 1990. Plant growth regulatory activities of artemisinin and its related compounds. Journal of chemical ecology 16(6): 1867-1876.

Conrath U, Beckers GJ, Flors V, García-Agustín P, Jakab G, Mauch F, Newman M-A, Pieterse CM, Poinssot B, Pozo MJ. 2006. Priming: getting ready for battle. Molecular Plant-Microbe Interactions 19(10): 1062-1071.

Cook C, Whichard LP, Turner B, Wall ME, Egley GH. 1966. Germination of witchweed (Striga lutea Lour.): isolation and properties of a potent stimulant. Science 154(3753): 1189-1190.

Dervinis C, Frost CJ, Lawrence SD, Novak NG, Davis JM. 2010. Cytokinin primes plant responses to wounding and reduces insect performance. Journal of Plant Growth Regulation 29(3): 289-296.

Dixon KW, Merritt DJ, Flematti GR, Ghisalberti EL. 2009. Karrikinolide - a phytoreactive compound derived from smoke with applications in horticulture, ecological restoration and agriculture. $\mathrm{Vi}$ International Symposium on New Floricultural Crops 813: 155-170.

Engelberth J, Alborn HT, Schmelz EA, Tumlinson JH. 2004. Airborne signals prime plants against insect herbivore attack. Proceedings of the National Academy of Sciences USA 101(6): 1781-1785.

Engelberth J, Seidl-Adams I, Schultz JC, Tumlinson JH. 2007. Insect elicitors and exposure to green leafy volatiles differentially upregulate major octadecanoids and transcripts of 12-Oxo Phytodienoic Acid Reductases in Zea mays. Molecular Plant-Microbe Interactions 20(6): 707-716.

Erb M, Veyrat N, Robert CA, Xu H, Frey M, Ton J, Turlings TC. 2015. Indole is an essential herbivoreinduced volatile priming signal in maize. Nature communications 6(6273): 6273.

Fenner M. 2000. Seeds: the ecology of regeneration in plant communities: Cabi.

Flematti GR, Ghisalberti EL, Dixon KW, Trengove RD. 2004. A compound from smoke that promotes seed germination. Science 305(5686): 977-977.

Flores J, Jurado E, Arredondo A. 2006. Effect of light on germination of seeds of Cactaceae from the Chihuahuan Desert, Mexico. Seed science research 16(2): 149-155.

Freundlich GE, Frost C. 2018. Variable costs of eavesdropping a green leaf volatile on two plant species in a common garden experiment. bioRxiv.

Friis EM, Crane PR, Pedersen KR. 2011. Early flowers and angiosperm evolution: Cambridge University Press.

Frost CJ, Appel HM, Carlson JE, De Moraes CM, Mescher MC, Schultz JC. 2007. Within-plant signalling via volatiles overcomes vascular constraints on systemic signalling and primes responses against herbivores. Ecology Letters 10(6): 490-498.

Frost CJ, Mescher MC, Carlson JE, De Moraes CM. 2008a. Plant defense priming against herbivores: getting ready for a different battle. Plant physiology 146(3): 818-824.

Frost CJ, Mescher MC, Carlson JE, De Moraes CM. 2008b. Why do distance limitations exist on plantplant signaling via airborne volatiles? Plant Signaling \& Behavior 3(7): 466-468.

Frost CJ, Mescher MC, Dervinis C, Davis JM, Carlson JE, De Moraes CM. 2008c. Priming defense genes and metabolites in hybrid poplar by the green leaf volatile cis-3-hexenyl acetate. New Phytologist 180(3): 722-734.

Frost CJ, Nyamdari B, Tsai C-J, Harding SA. 2012. The tonoplast-localized sucrose transporter in Populus (PtaSUT4) regulates whole-plant water relations, responses to water stress, and photosynthesis. PloS one 7(8): e44467.

Gao L-L, Klingler JP, Anderson JP, Edwards OR, Singh KB. 2008. Characterization of pea aphid resistance in Medicago truncatula. Plant physiology 146: 996-1009.

Gao LL, Anderson JP, Klingler JP, Nair RM, Edwards OR, Singh KB. 2007. Involvement of the octadecanoid pathway in bluegreen aphid resistance in Medicago truncatula. Molecular PlantMicrobe Interactions 20(1): 82-93. 
Gasmi L, Martinez-Solis M, Frattini A, Ye M, Collado MC, Turlings T, Erb M, Herrero S. 2018. Can herbivore-induced volatiles protect plants by increasing the herbivores' susceptibility to natural pathogens? bioRxiv.

GenScript C. 2006. Real-time PCR primer design. GenScript Corporation.

Gfeller A, Laloux M, Barsics F, Kati DE, Haubruge E, du Jardin P, Verheggen FJ, Lognay G, Wathelet J-P, Fauconnier M-L. 2013. Characterization of volatile organic compounds emitted by barley (Hordeum vulgare L.) roots and their attractiveness to wireworms. Journal of chemical ecology 39(8): 1129-1139.

Gutterman Y. 1994. Strategies of seed dispersal and germination in plants inhabiting deserts. The botanical review 60(4): 373-425.

H B Tukey J. 1970. The leaching of substances from plants. Annual Review of Plant Physiology 21(1): 305-324.

Herms DA, Mattson WJ. 1992. The dilemma of plants: to grow or defend. The Quarterly Review of Biology 67(3): 283-335.

Hilker M, Schwachtje J, Baier M, Balazadeh S, Bäurle I, Geiselhardt S. 2016. Priming and memory of stress responses in organisms lacking a nervous system. Biological Reviews Cambridge Philosophical Society 91: 1118-1133.

Hopkins R, Griffiths D, Birch A, McKinlay R. 1998. Influence of increasing herbivore pressure on modification of glucosinolate content of swedes (Brassica napus spp. rapifera). Journal of chemical ecology 24(12): 2003-2019.

Jucelaine H, Ricardi LE, Shimomura HK, Miguel MS, Edgar SV, M. PG. 2018. Getting ready for battle: do cabbage seeds treated with jasmonic acid and chitosan affect chewing and sap-feeding insects? Entomologia Experimentalis et Applicata 166(5): 412-419.

Kanchiswamy CN, Malnoy M, Maffei ME. 2015. Chemical diversity of microbial volatiles and their potential for plant growth and productivity. Frontiers in plant science 6: 151.

Karban R. 2007. Experimental clipping of sagebrush inhibits seed germination of neighbours. Ecology Letters 10(9): 791-797.

Karssen CM, Hilhorst HWM 2000. Effect of chemical environment on seed germination. In: Fenner M ed. Seeds. The ecology of regeneration in plants communities: Cabi, 293-309.

Koitabashi R, Suzuki T, Kawazu T, Sakai A, Kuroiwa H, Kuroiwa T. 1997. 1,8-Cineole inhibits root growth and DNA synthesis in the root apical meristem of Brassica campestris L. Journal of Plant Research 110(1): 1-6.

Kuśnierczyk A, Winge P, Midelfart H, Armbruster WS, Rossiter JT, Bones AM. 2007. Transcriptional responses of Arabidopsis thaliana ecotypes with different glucosinolate profiles after attack by polyphagous Myzus persicae and oligophagous Brevicoryne brassicae. Journal of Experimental Botany 58(10): 2537-2552.

Laetz CA, Baldwin DH, Collier TK, Hebert V, Stark JD, Scholz NL. 2009. The Synergistic Toxicity of Pesticide Mixtures: Implications for Risk Assessment and the Conservation of Endangered Pacific Salmon. Environmental Health Perspectives 117(3): 348-353.

Lawo NC, Weingart GJF, Schuhmacher R, Forneck A. 2011. The volatile metabolome of grapevine roots: First insights into the metabolic response upon phylloxera attack. Plant Physiology and Biochemistry 49(9): 1059-1063.

Lee J-H, Wood TK, Lee J. 2015. Roles of indole as an interspecies and interkingdom signaling molecule. Trends in Microbiology 23(11): 707-718.

Levine JM, McEachern AK, Cowan C. 2008. Rainfall effects on rare annual plants. Journal of Ecology 96(4): 795-806. 
Liu J, Maldonado-Mendoza I, Lopez-Meyer M, Cheung F, Town CD, Harrison MJ. 2007. Arbuscular mycorrhizal symbiosis is accompanied by local and systemic alterations in gene expression and an increase in disease resistance in the shoots. The Plant Journal 50: 529-544.

Livak KJ, Schmittgen TD. 2001. Analysis of relative gene expression data using real-time quantitative PCR and the $2^{-\Delta \Delta C T}$ Method. Methods 25: 402-408.

Martínez-Medina A, Van Wees S, Pieterse CM. 2017. Airborne signals by Trichoderma fungi stimulate iron uptake responses in roots resulting in priming of jasmonic acid-dependent defences in shoots of Arabidopsis thaliana and Solanum lycopersicum. Plant, cell \& environment 40: 26912705.

Milberg P, Andersson L, Thompson K. 2000. Large-seeded spices are less dependent on light for germination than small-seeded ones. Seed science research 10(1): 99-104.

Mirabella R, Rauwerda H, Struys EA, Jakobs C, Triantaphylidès C, Haring MA, Schuurink RC. 2008. The Arabidopsis her1 mutant implicates GABA in E-2-hexenal responsiveness. The Plant Journal 53(2): 197-213.

Moran PJ, Thompson GA. 2001. Molecular responses to aphid feeding in arabidopsis in relation to plant defense pathways. Plant physiology 125(2): 1074-1085.

Muller CH, Muller WH, Haines BL. 1964. Volatile growth inhibitors produced by aromatic shrubs. Science 143(3605): 471-473.

Muller WH. 1965. Volatile materials produced by Salvia leucophylla: effects on seedling growth and soil bacteria. Botanical Gazette 126(3): 195-200.

Muller WH, Muller CH. 1964. Volatile growth inhibitors produced by Salvia species. Bulletin of the Torrey Botanical Club: 327-330.

Muscolo A, Panuccio MR, Sidari M. 2001. The effect of phenols on respiratory enzymes in seed germination. Plant Growth Regulation 35(1): 31-35.

Nelson DC, Flematti GR, Ghisalberti EL, Dixon KW, Smith SM. 2012. Regulation of seed germination and seedling growth by chemical signals from burning vegetation. Annual review of plant biology 63(1): 107-130.

Ninkovic V. 2003. Volatile communication between barley plants affects biomass allocation. Journal of Experimental Botany 54(389): 1931-1939.

Oleszek W. 1987. Allelopathic effects of volatiles from some Cruciferae species on lettuce, barnyard grass and wheat growth. Plant and Soil 102(2): 271-273.

Pake CE, Venable DL. 1996. Seed banks in desert annuals: Implications for persistence and coexistence in variable environments. Ecology 77(5): 1427-1435.

Palma R, Mutis A, Manosalva L, Ceballos R, Quiroz A. 2012. Behavioral and electrophysiological responses of Hylastinus obscurus to volatiles released from the roots of Trifolium pratense $\mathrm{L}$. Journal of soil science and plant nutrition 12(1): 183-193.

Paparella S, Araújo SS, Rossi G, Wijayasinghe M, Carbonera D, Balestrazzi A. 2015. Seed priming: state of the art and new perspectives. Plant Cell Reports 34(8): 1281-1293.

Peñuelas J, Asensio D, Tholl D, Wenke K, Rosenkranz M, Piechulla B, Schnitzler JP. 2014. Biogenic volatile emissions from the soil. Plant, cell \& environment 37(8): 1866-1891.

Pichersky E, Gershenzon J. 2002. The formation and function of plant volatiles: perfumes for pollinator attraction and defense. Current opinion in plant biology 5(3): 237-243.

Pickett JA, Khan ZR. 2016. Plant volatile-mediated signalling and its application in agriculture: successes and challenges. New Phytologist 212(4): 856-870.

Preston CA, Betts H, Baldwin IT. 2002. Methyl jasmonate as an allelopathic agent: sagebrush inhibits germination of a neighboring tobacco, Nicotiana Attenuata. Journal of chemical ecology 28(11): 2343-2369. 
Probert RJ 2000. The role of temperature in the regulation of seed dormancy and germination. In: Fenner M ed. Seeds: the ecology of regeneration in plant communities: CABI, 261-292.

Rajjou L, Belghazi M, Huguet R, Robin C, Moreau A, Job C, Job D. 2006. Proteomic investigation of the effect of salicylic acid on arabidopsis seed germination and establishment of early defense mechanisms. Plant physiology 141(3): 910-923.

Reymond P, Bodenhausen N, Van Poecke RMP, Krishnamurthy V, Dicke M, Farmer EE. 2004. A conserved transcript pattern in response to a specialist and a generalist herbivore. Plant Cell 16: 3132-3147.

Reynolds SA, Corbin JD, D'Antonio CM. 2001. The effects of litter and temperature on the germination of native and exotic grasses in a coastal California grassland. Madrono 48(4): 230-235.

Rodriguez-Saona CR, Frost CJ. 2010. New evidence for a multi-functional role of herbivore-induced plant volatiles in defense against herbivores. Plant Signaling \& Behavior 5(1): 58-60.

Rodriguez-Saona CR, Rodriguez-Saona LE, Frost CJ. 2009. Herbivore-induced volatiles in the perennial shrub, Vaccinium corymbosum, and their role in inter-branch signaling. Journal of chemical ecology 35(2): 163-175.

Rudrappa T, Biedrzycki ML, Kunjeti SG, Donofrio NM, Czymmek KJ, Paul W P, Bais HP. 2010. The rhizobacterial elicitor acetoin induces systemic resistance in Arabidopsis thaliana. Communicative \& Integrative Biology 3(2): 130-138.

Ryu C, Farag MA, Hu C, Reddy MS, Kloepper JW, Pare PW. 2004. Bacterial volatiles induce systemic resistance in Arabidopsis. Plant physiology 134(3): 1017-1026.

Seo M, Nambara E, Choi G, Yamaguchi S. 2008. Interaction of light and hormone signals in germinating seeds. Plant Molecular Biology 69(4): 463.

Sharifi R, Ryu C-M. 2016. Are bacterial volatile compounds poisonous odors to a fungal pathogen Botrytis cinerea, alarm signals to Arabidopsis seedlings for eliciting induced resistance, or both? Frontiers in microbiology 7: 196.

Simonin KA, Roddy AB. 2018. Genome downsizing, physiological novelty, and the global dominance of flowering plants. PLoS biology 16(1): e2003706.

Smart LE, Martin JL, Limpalaër M, Bruce TJA, Pickett JA. 2013. Responses of herbivore and predatory mites to tomato plants exposed to jasmonic acid seed treatment. Journal of chemical ecology 39(10): 1297-1300.

Song GC, Choi HK, Ryu C-M. 2015. Gaseous 3-pentanol primes plant immunity against a bacterial speck pathogen, Pseudomonas syringae pv. tomato via salicylic acid and jasmonic acid-dependent signaling pathways in Arabidopsis. Frontiers in plant science 6(821).

Song GC, Ryu CM. 2013. Two volatile organic compounds trigger plant self-defense against a bacterial pathogen and a sucking insect in cucumber under open field conditions. International Journal of Molecular Sciences 14.

Thelen GC, Vivanco JM, Newingham B, Good W, Bais HP, Landres P, Caesar A, Callaway RM. 2005. Insect herbivory stimulates allelopathic exudation by an invasive plant and the suppression of natives. Ecology Letters 8(2): 209-217.

Toh S, Imamura A, Watanabe A, Nakabayashi K, Okamoto M, Jikumaru Y, Hanada A, Aso Y, Ishiyama K, Tamura N. 2008. High temperature-induced abscisic acid biosynthesis and its role in the inhibition of gibberellin action in Arabidopsis seeds. Plant physiology 146(3): 1368-1385.

Tomczak VV, Müller C. 2017. Influence of arbuscular mycorrhizal stage and plant age on the performance of a generalist aphid. Journal of Insect Physiology 98: 258-266.

van Hulten M, Pelser M, van Loon LC, Pieterse CMJ, Ton J. 2006. Costs and benefits of priming for defense in Arabidopsis. Proceedings of the National Academy of Sciences USA 103(14): 56025607. 
Veyrat N, Robert CAM, Turlings TCJ, Erb M. 2016. Herbivore intoxication as a potential primary function of an inducible volatile plant signal. Journal of Ecology 104(2): 591-600.

Walling LL. 2008. Avoiding effective defenses: strategies employed by phloem-feeding insects. Plant physiology 146: 859-866.

War AR, Paulraj MG, War MY, Ignacimuthu S. 2011. Herbivore- and elicitor- induced resistance in groundnut to asian armyworm, Spodoptera litura (Fab.) (Lepidoptera: Noctuidae). Plant Signaling \& Behavior 6(11): 1769-1777.

Wasternack C. 2007. Jasmonates: An update on biosynthesis, signal transduction and action in plant stress response, growth and development. Annals of botany 100: 681-697.

Wesson G, Wareing PF. 1969. The role of light in the germination of naturally occurring populations of buried weed seeds. Journal of Experimental Botany 20(2): 402-413.

Worrall D, Holroyd GH, Moore JP, Glowacz M, Croft P, Taylor JE, Paul ND, Roberts MR. 2012. Treating seeds with activators of plant defence generates long-lasting priming of resistance to pests and pathogens. New Phytologist 193(3): 770-778.

Yang C, Hu L, Ali B, Islam F, Bai Q, Yun X, Yoneyama K, Zhou W. 2016. Seed treatment with salicylic acid invokes defence mechanism of Helianthus annuus against Orobanche cumana. Annals of Applied Biology 169(3): 408-422.

Ye M, Veyrat N, Xu H, Hu L, Turlings TCJ, Erb M. 2018. An herbivore-induced plant volatile reduces parasitoid attraction by changing the smell of caterpillars. Science Advances 4(5): eaar4767.

Yu SM, Lee YH. 2013. Plant growth promoting rhizobacterium Proteus vulgaris JBLS202 stimulates the seedling growth of Chinese cabbage through indole emission. Plant and Soil 370(1-2): 485-495.

Zhang R, Wang B, Ouyang J, Li J, Wang Y. 2008. Arabidopsis indole synthase, a homolog of tryptophan synthase alpha, is an enzyme involved in the trp-independent indole-containing metabolite biosynthesis. Journal of Integrative Plant Biology 50(9): 1070-1077.

Zhao Y, Hull AK, Gupta NR, Goss KA, Alonso J, Ecker JR, Normanly J, Chory J, Celenza JL. 2002. Trpdependent auxin biosynthesis in Arabidopsis: involvement of cytochrome P450s CYP79B2 and CYP79B3. Genes \& development 16(23): 3100-3112.

\section{Acknowledgements}

This work was supported financially by a National Science Foundation grant IOS1656625 to C.J.F. We thank Dr. Julia Frugoli for generously providing M. truncatula, A-17 seeds and Dr. Susana Karen Gomez for supplying the pea aphids. We are thankful to Grace Freundlich, Allie Peot and Rachel Haslem for lab assistance.

\section{Author Contributions}

C.J.F. and A.K.M. designed the research. A.K.M. conducted experiments. A.K.M. and L.P. performed quantitative RT-PCR. A.K.M. and C.J.F. analyzed data and wrote the manuscript. All authors read and approved the manuscript.

Competing Financial Interests: The authors declare no competing financial interests 
625 Table 1 Primer sequences used in this study.

626

\begin{tabular}{|c|c|c|c|c|}
\hline Plant & Genes & $\begin{array}{l}\text { Primer sequence } \\
\qquad\left(5^{\prime} \rightarrow 3^{\prime}\right)\end{array}$ & $\begin{array}{l}\text { Ampli } \\
\text {-con } \\
\text { length } \\
\text { (pb) }\end{array}$ & Reference \\
\hline \multirow{6}{*}{$\begin{array}{l}\text { Arabidopsis } \\
\text { thaliana }\end{array}$} & $\operatorname{Actin} 7$ & $\begin{array}{l}\text { F: AGTGGTCGTACAACCGGTATTGT } \\
\text { R: GATAGCATGAGGAAGAGCATACC }\end{array}$ & 91 & $\begin{array}{l}\text { (Martínez- } \\
\text { Medina et } \\
\text { al., 2017) }\end{array}$ \\
\hline & $G A P D H$ & $\begin{array}{l}\text { F: CCATGGGCCGAGGCTGGAG } \\
\text { R: ACCTTCTTGGCACCACCCTTCA }\end{array}$ & 101 & $\begin{array}{c}\text { GenScript } \\
\text { (GenScript, } \\
\text { 2006) }\end{array}$ \\
\hline & $L O X 2$ & $\begin{array}{l}\text { F: AAGAGTTCTATGAGTCGCCAGA } \\
\text { R: TGTACTCTTCGTCAGGTGAATG }\end{array}$ & 119 & $\begin{array}{l}\text { (Kuśnierczyk } \\
\text { et al., 2007) }\end{array}$ \\
\hline & MYC2 & $\begin{array}{l}\text { F: CGGAGATCGAGTTCGCCGCC } \\
\text { R: AATCCCGCACCGCAAGCGAA }\end{array}$ & 191 & $\begin{array}{c}\text { GenScript } \\
\text { (GenScript, } \\
\text { 2006) }\end{array}$ \\
\hline & CYP79B2 & $\begin{array}{l}\text { F: ATCACATCCCTAAAGGAAGTCA } \\
\text { R: CCGGTACTGAACGAGATAAACC }\end{array}$ & 165 & $\begin{array}{l}\text { (Kuśnierczyk } \\
\text { et al., 2007) }\end{array}$ \\
\hline & СYР79B3 & $\begin{array}{l}\text { F: GGTTTGGTCTGATCCACTTAGC } \\
\text { R: CTAGCATCATGGTCGTTATCGC }\end{array}$ & 160 & $\begin{array}{l}\text { (Kuśnierczyk } \\
\text { et al., 2007) }\end{array}$ \\
\hline \multirow{4}{*}{$\begin{array}{l}\text { Medicago } \\
\text { truncatula }\end{array}$} & EF1a & $\begin{array}{l}\text { F: TGACAGGCGATCTGGTAAGG } \\
\text { R: CAGCGAAGGTCTCAACCAC }\end{array}$ & 108 & $\begin{array}{l}\text { (Liu et al., } \\
\text { 2007) }\end{array}$ \\
\hline & GAPDH & $\begin{array}{l}\text { F: AACATCATTCCCAGCAGCAC } \\
\text { R: AACATCGACGGTAGGCACAC }\end{array}$ & 108 & $\begin{array}{l}\text { (Liu et al., } \\
\text { 2007) }\end{array}$ \\
\hline & PR5 & $\begin{array}{l}\text { F: TGCCTTAGCTTTGCATTCCT } \\
\text { R: AATTTCCGCTGAGTTCGTTG }\end{array}$ & 168 & $\begin{array}{l}\text { (Gao et al., } \\
\text { 2007) }\end{array}$ \\
\hline & $B G L$ & $\begin{array}{l}\text { F: CAAATTGGGTCCAAAAATATGTGAC } \\
\text { R: GCACCATCATTGGGTGGATATGAAG }\end{array}$ & 229 & $\begin{array}{l}\text { (Gao et al., } \\
\text { 2007) }\end{array}$ \\
\hline
\end{tabular}




\section{Figure Legends}

630

631

Fig. 1 The effect of seed exposure to plant volatiles on the herbivore fitness (a) Relative growth rate (RGR) of $S$. exigua caterpillars after $24 \mathrm{~h}$ herbivory on $A$. thaliana plants grown from control and volatile-exposed seeds ( $n=6$, each biological replicate had 1-3 technical replicates),

(b) Relative growth rate of $S$. exigua caterpillars after $24 \mathrm{~h}$ herbivory on $A$. thaliana plants grown from control and indole-exposed seeds in a separate caterpillar herbivory experiment $(n=8-10$, each biological replicate had 1-3 technical replicates), (c) Fecundity (nymph number per adult) and, (d) nymph weight after 14 days of herbivory on M. truncatula plant grown from control and volatile-exposed seed $(n=6-8)$. Values are shown as means $\pm 95 \%$ CI and significance was calculated by student's $t$-test (two-tailed).

Fig. 2 Seeds exposure to plant volatiles does not affect $A$. thaliana plants growth and reproductive output. The effect of seed exposure to plant derived volatiles on (a) Leaf number, DPS represents days after seed sowing. Values are shown as means $\pm 95 \%$ CI $(n=8-10)$. Seed exposure to $e 2 \mathrm{HAL}$ reduced the seed germination on agar plates (e) Percent seed germination. Values are shown as means $\pm \operatorname{SEM}(n=90)$. Significance was calculated by repeated measures ANOVA and one-way ANOVA.

Fig. 3 Seeds exposure to cis configuration green leaf volatiles enhances growth of Medicago truncatula. (a) Picture of control and z3HAC seed exposed M. truncatula plants. The effect of

652 seed exposure to plant derived volatiles on (b) leaf petiole length, (c) Leaf blade length, (d) Leaf 653 blade width and, (e) axillary shoot length. For leaf petiole length, leaf blade length and width all 654 the measurements were taken when the leaves were fully developed. Axillary shoot was 655 measured at 64 days after seed sowing. Values for each metamer are shown as means $+95 \% \mathrm{CI}$ $656(n=5-10)$ and asterisks represent significant differences $(\mathrm{p}<0.05)$ from controls based on one-way 657 ANOVA followed by Dunnett's post-hoc analysis. 
659 Fig. 4. Seed treatment with indole does not enhance herbivore-induced expression of defense

660 marker genes. Relative transcript levels of the genes $L O X 2, M Y C 2, C Y B-B 2$ and $C Y B-B 3$ in $A$.

661 thaliana after $24 \mathrm{~h}$ of $S$. exigua herbivory was measured by quantitative RT-PCR analysis (a-d).

662 Similarly, transcript levels of SA regulated marker genes $P R 5$ and $B G L$ were measured in $M$.

663 trunacatula after 14 days of pea aphid herbivory (e \& f). Relative expression was determined ( $2^{-}$

$664{ }_{\Delta}{ }^{\mathrm{Ct}}$ ) using the geometric mean of two housekeeping genes for normalization. Bars represent mean

$665 \pm$ SEM determined from three-five biological replicate assays, each biological replicate had two

666 technical replicates. Different letters on the bar represent significant difference $(\mathrm{p}<0.05)$.

667

668 
Fig. 1

(a)
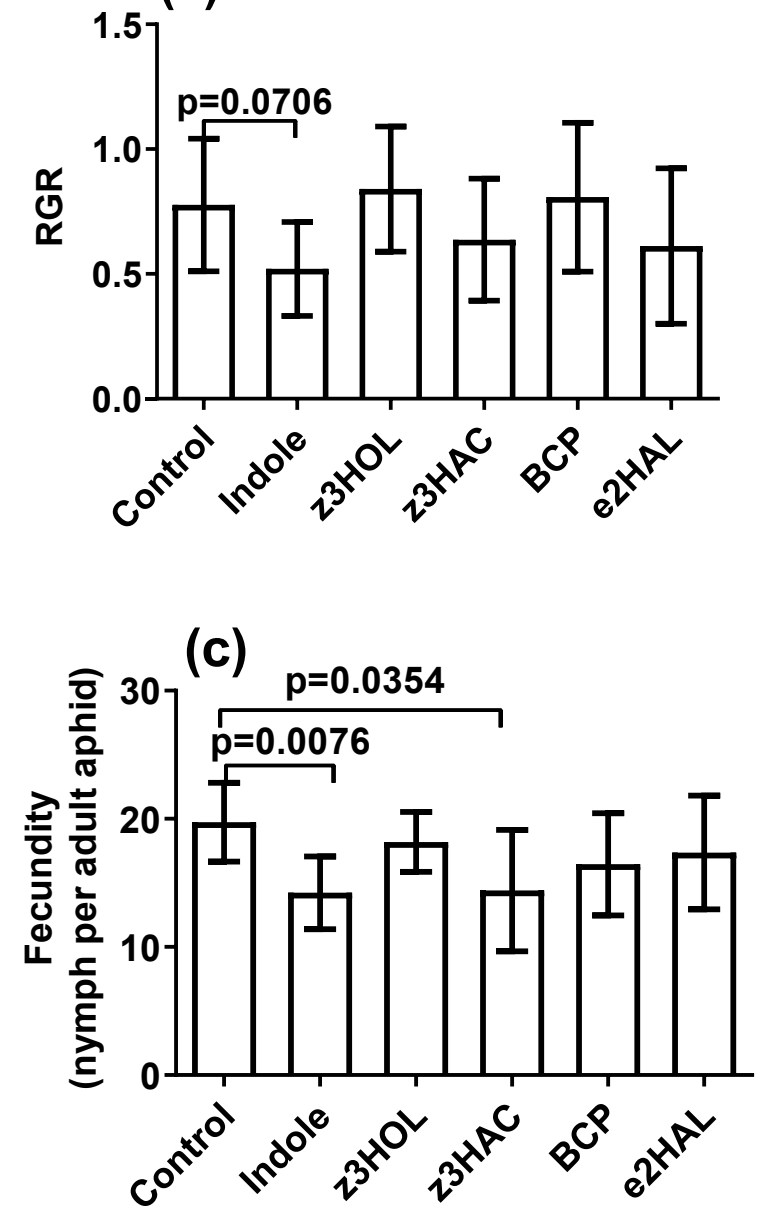

(b)
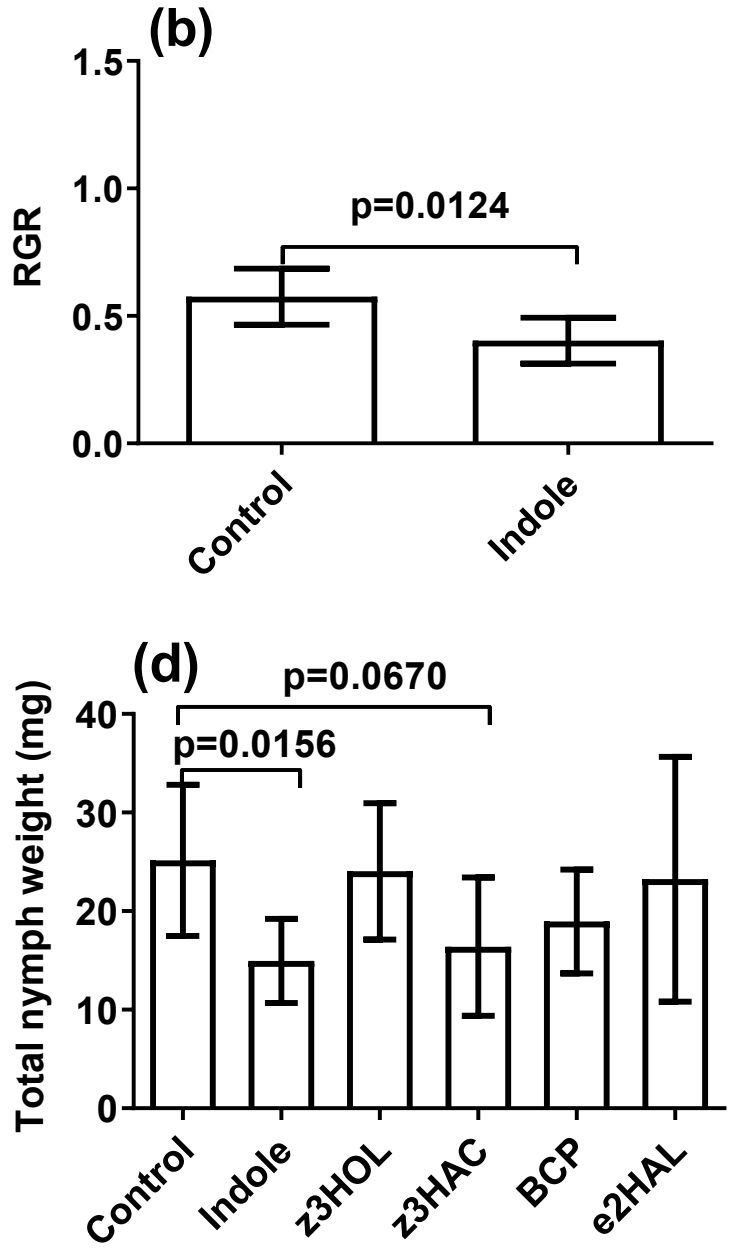

670

671 
Fig. 2
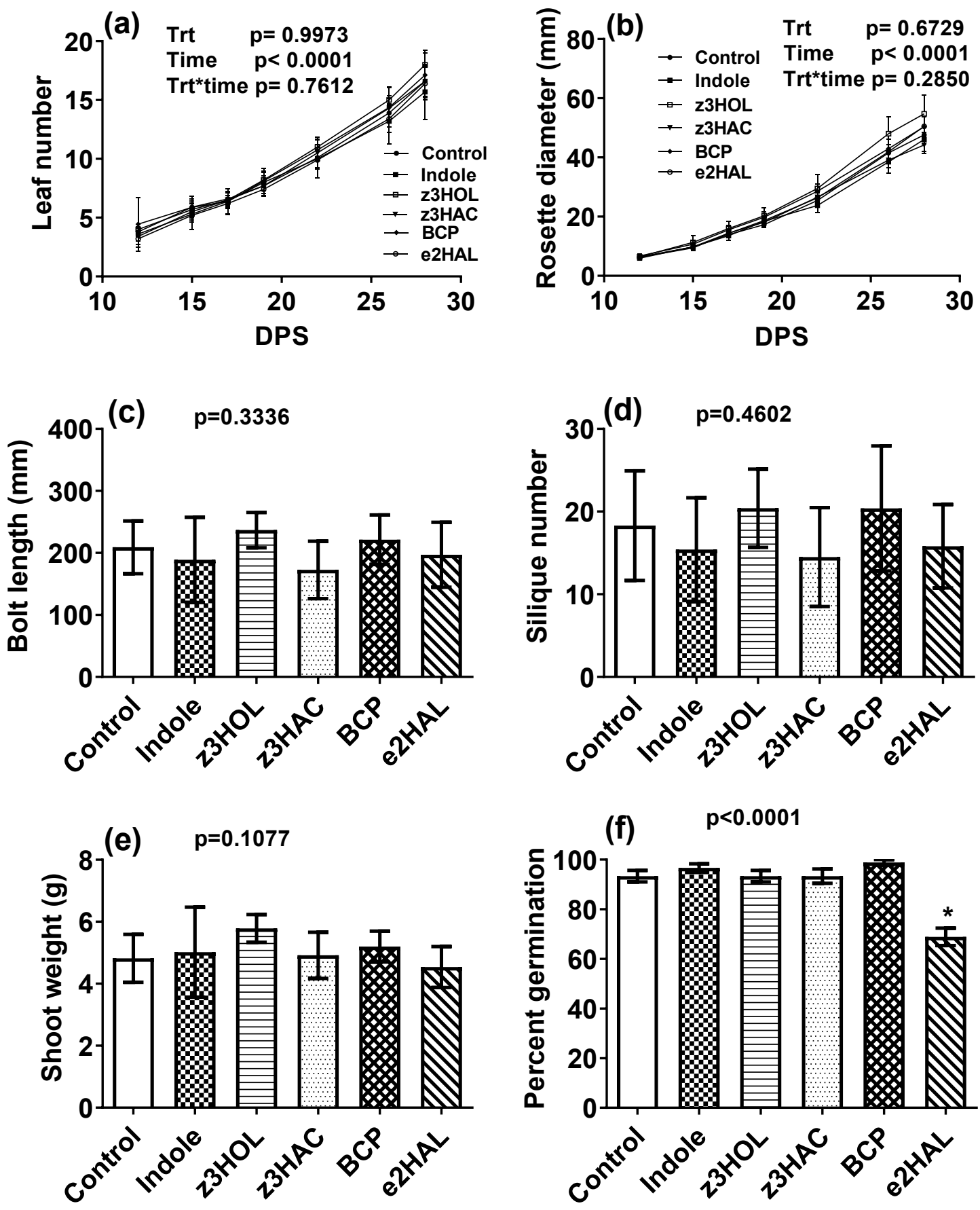

674

675 
bioRxiv preprint doi: https://doi org/10.1101/522839; this version posted January 17,2019 . The copyright holder for this preprint (which was not certified by peer review) is the author/funder, who has granted bioRxiv a license to display the preprint in perpetuity. It is made available under aCC-BY-NC-ND 4.0 International license.

Fig. 3

(a)
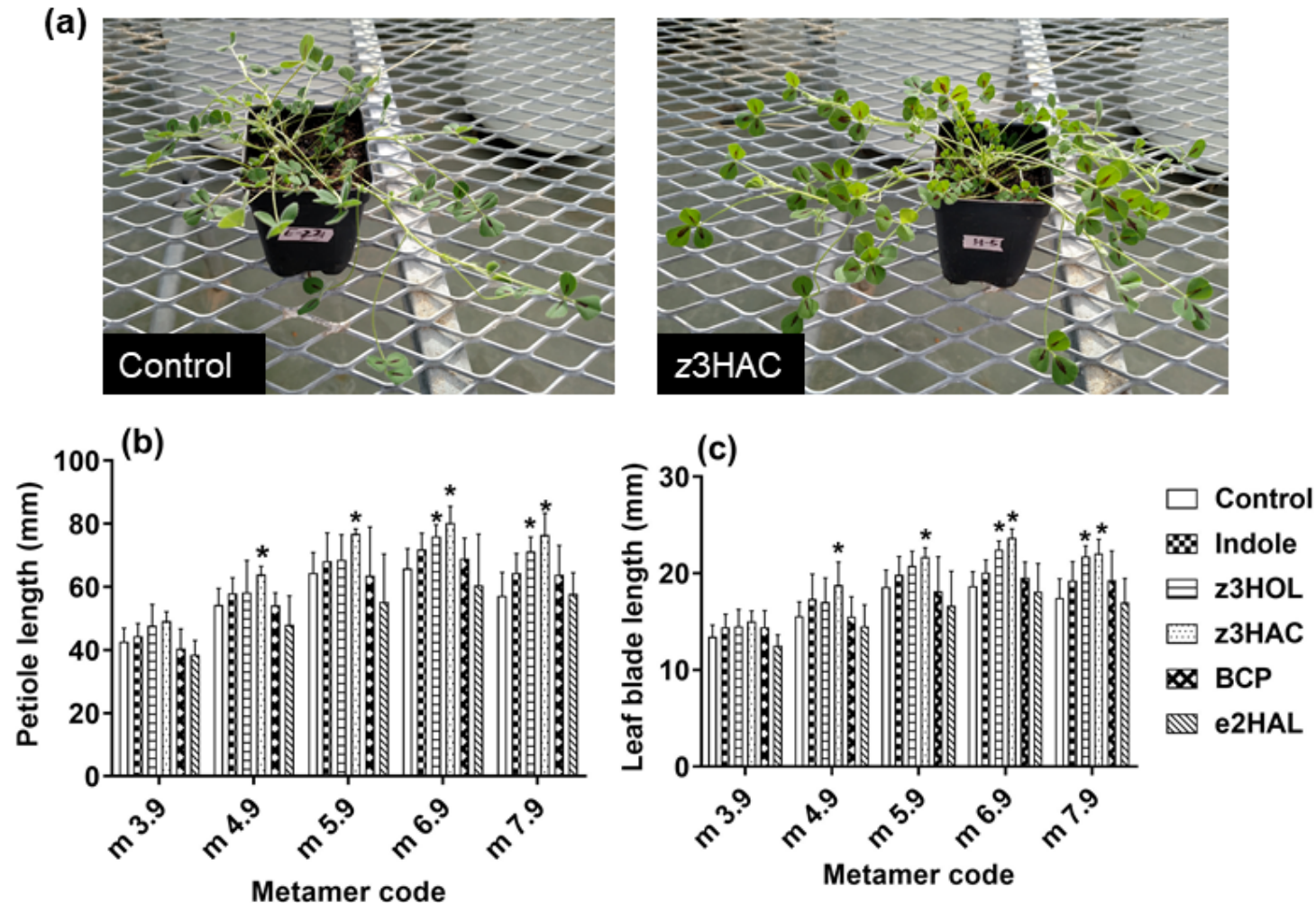

677

(d)

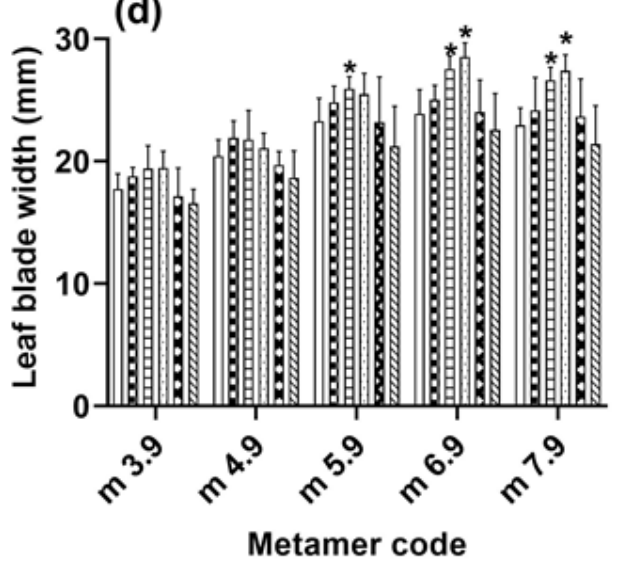

(f)

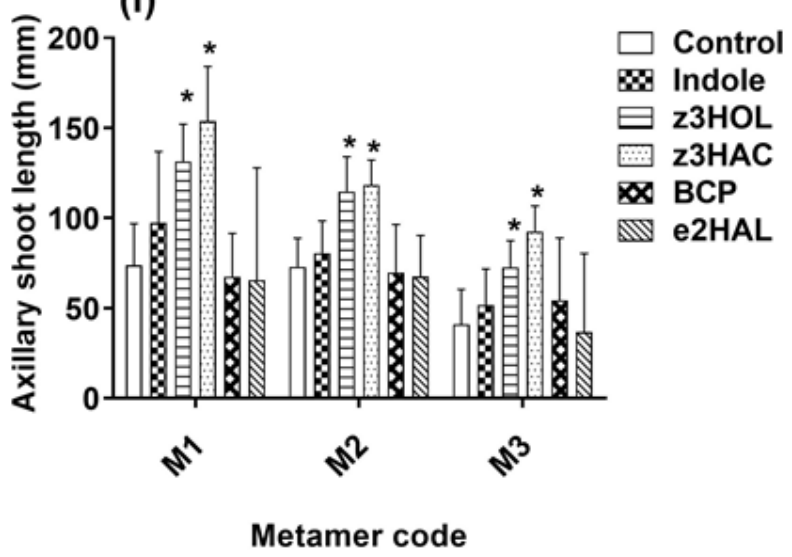

678 
Fig. 4
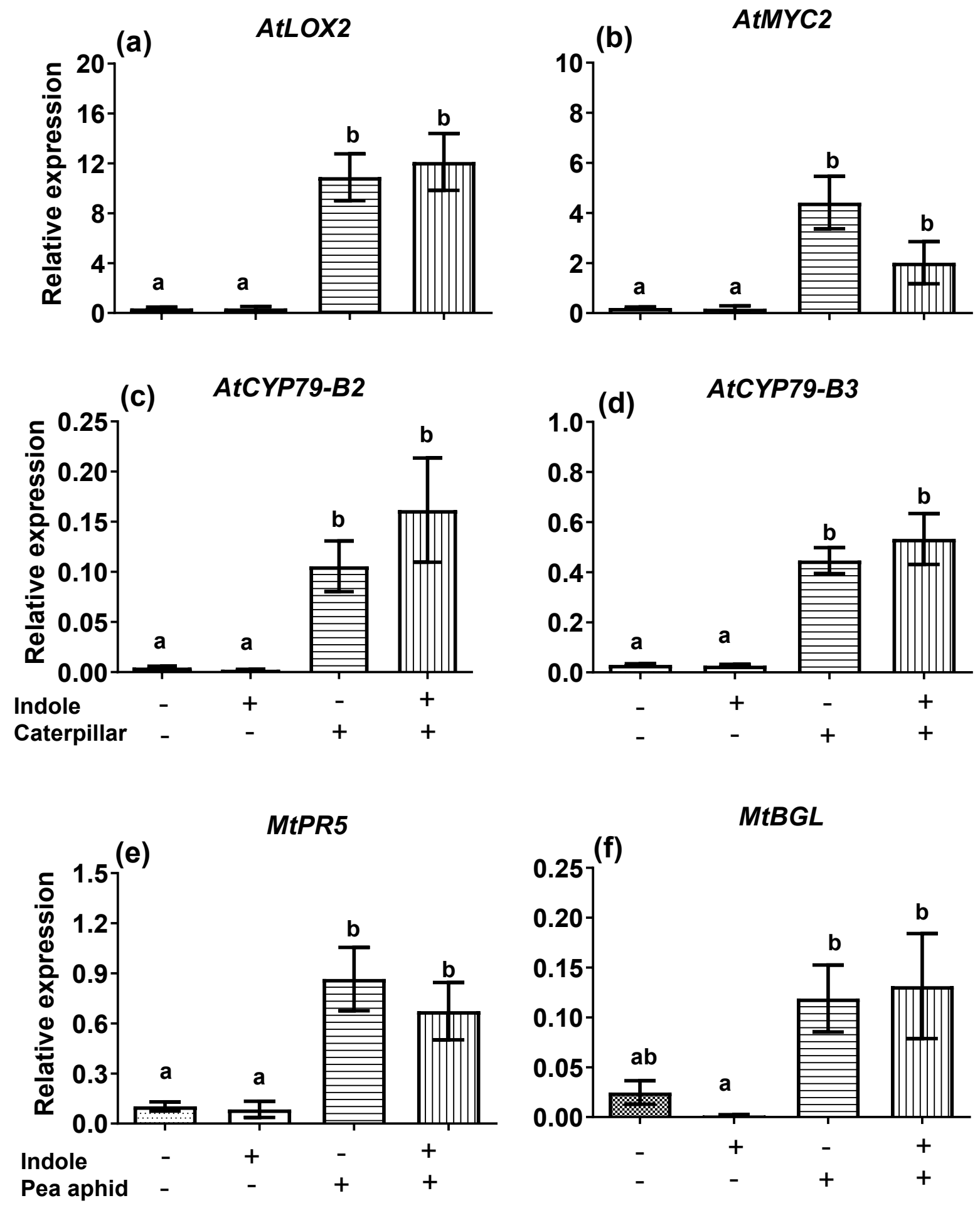
bioRxiv preprint doi: https://doi.org/10.1101/522839; this version posted January 17,2019 . The copyright holder for this preprint (which was not certified by peer review) is the author/funder, who has granted bioRxiv a license to display the preprint in perpetuity. It is made available under aCC-BY-NC-ND 4.0 International license.

\section{Supplemental Information}

684 Fig. S1 Pictorial representation of volatile dispensers used to expose seeds to synthetic plant 685 volatiles.

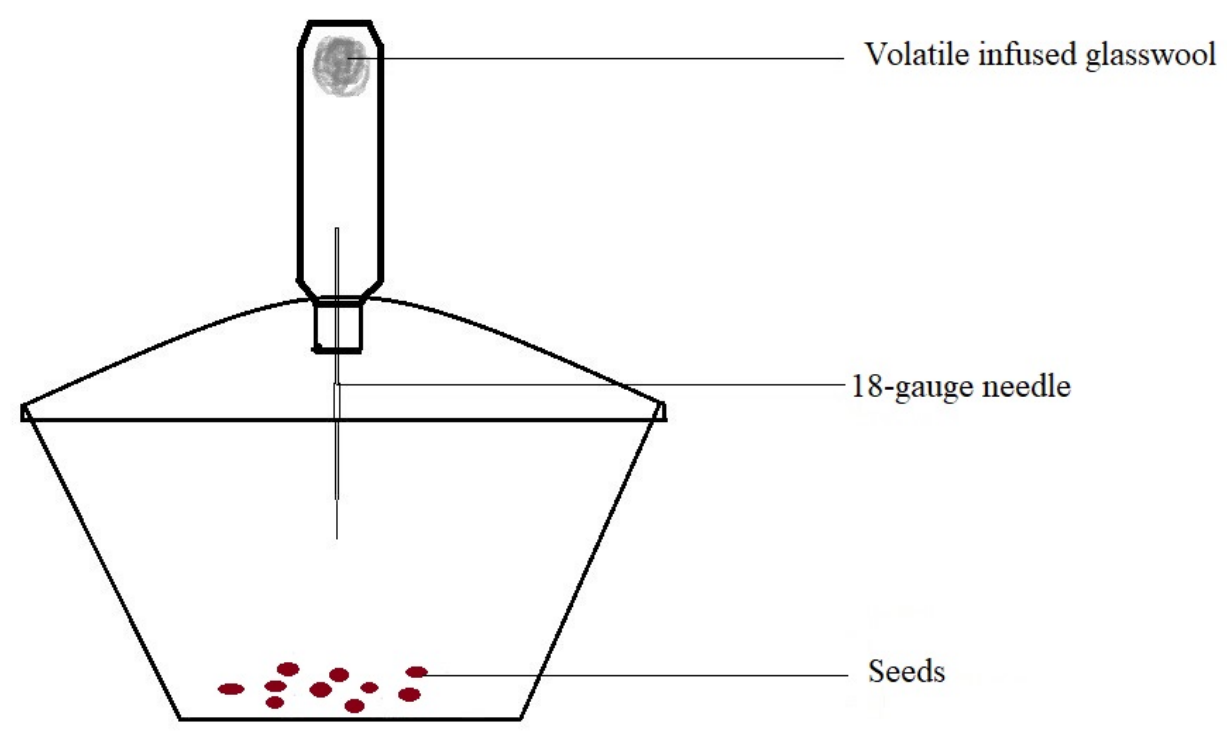

686 
689 Fig. S2 Seed exposure to plant derived volatiles have no effect on (a) Main shoot length and (b)

690 Total fruit number of M. truncatula plants. Values are shown as means $\pm 95 \% \mathrm{CI}(\mathrm{n}=5-10)$

691 significance was calculated by one-way ANOVA followed by Dunnett's post-hoc test.

692

693

694
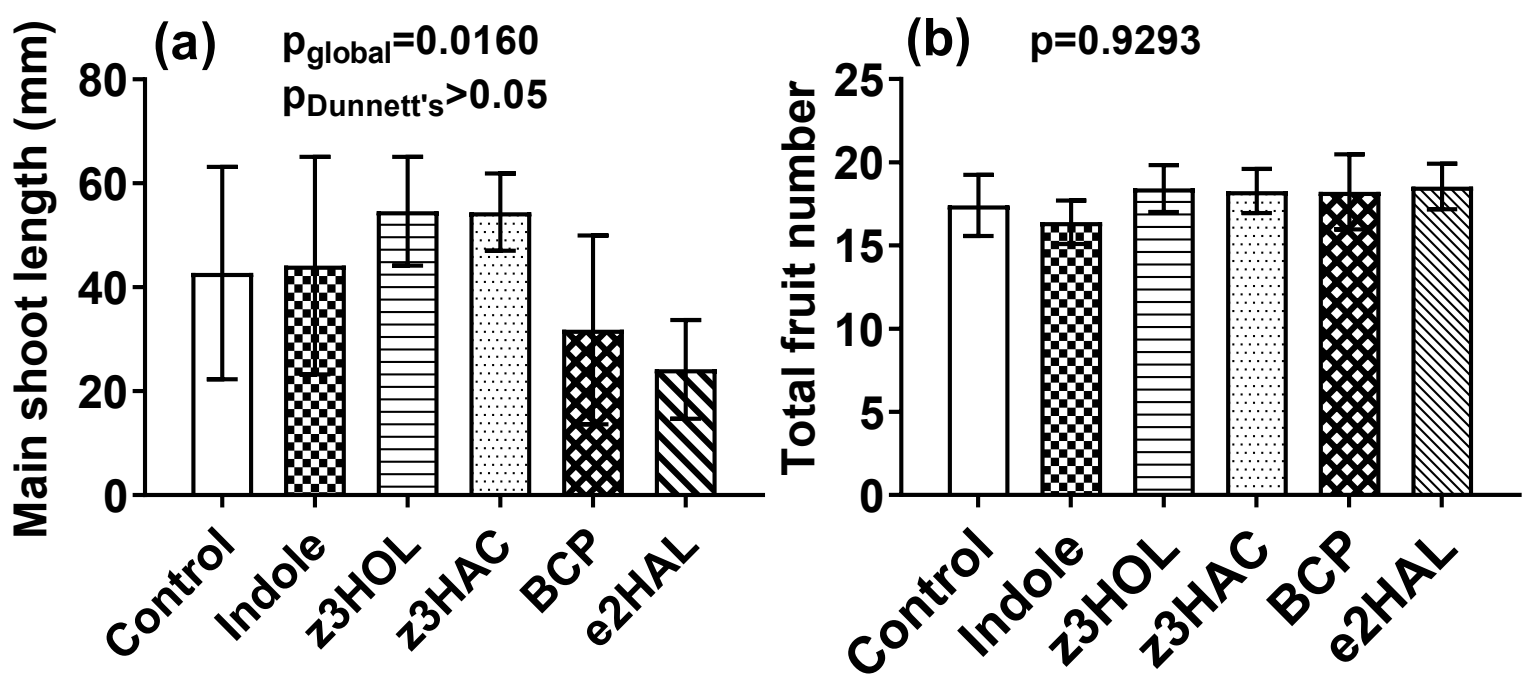
Fig. S3 Pictorial representation of the numerical nomenclature coding system for vegetative growth of $M$. truncatula. Nomenclature coding started with unifoliate leaf as first metamers and subsequent trifoliate are labeled along the main shoot in ascending order. Axillary shoots are named as per the metamer of origin.

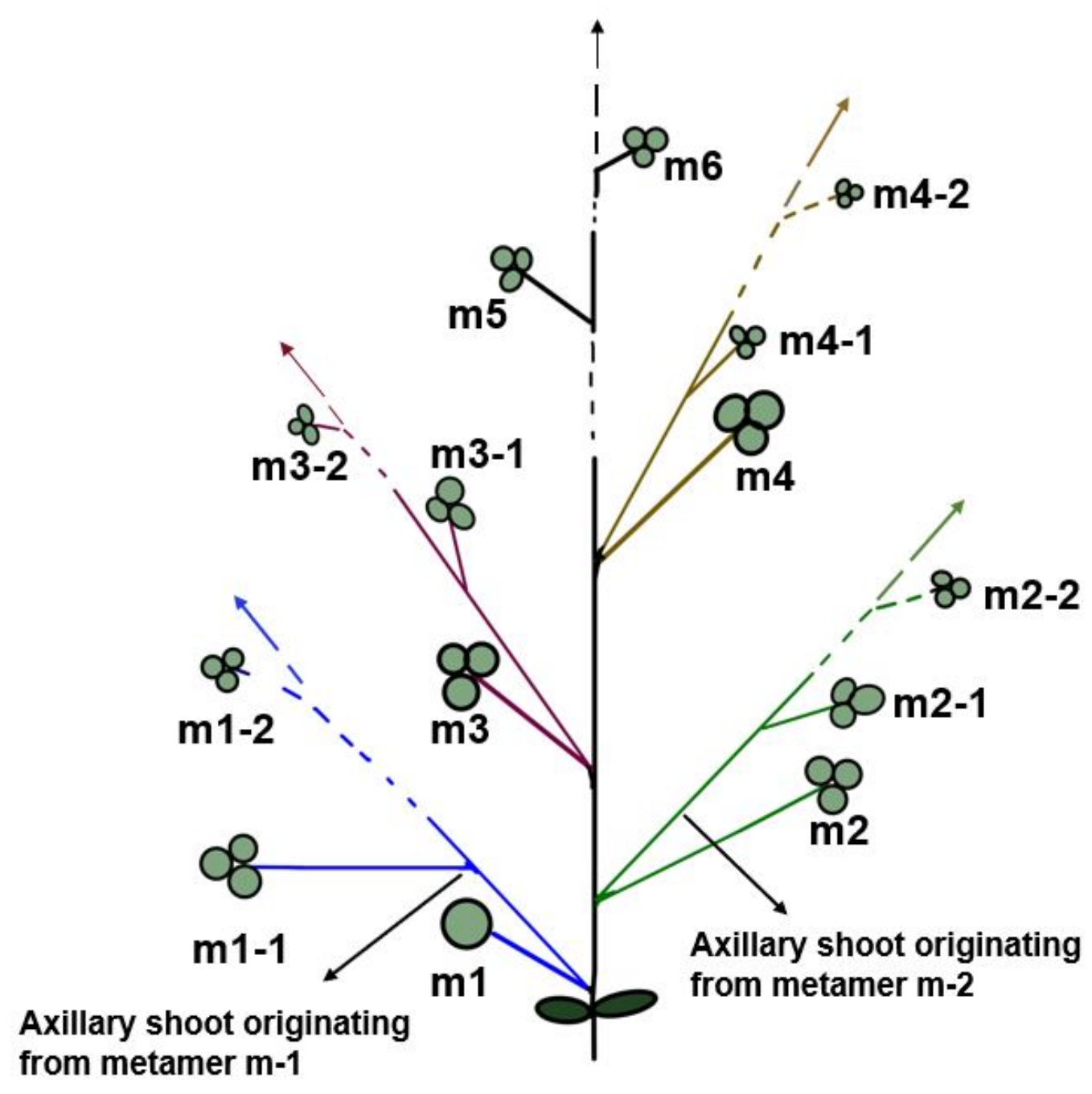

